\title{
Isoenzymes of alkaline phosphatase in epileptic patients receiving carbamazepine monotherapy
}

\author{
A B Okesina, D Donaldson, P T Lascelles
}

\begin{abstract}
The effects of carbamazepine monotherapy were investigated in 20 female and 21 male epileptic patients to determine whether treatment would induce an increase in serum alkaline phosphatase (ALP) activity, a known effect of many anticonvulsant drugs. Serum total ALP activity was increased in nine out of the 41 patients (22\%), serum bone ALP activity was increased in $10(24 \%)$, and serum non-bone ALP activity was increased in three $(7 \%)$. There was no significant difference when the mean of the patients'.serum total ALP was compared with that of the controls.

Twenty per cent of the patients with increased serum bone ALP had normal serum total ALP, indicating that increased serum bone isoenzyme activity may precede an increase in the total enzyme activity. This should be considered when interpreting results of increased total ALP in epileptic patients.
\end{abstract}

An increase in the activity of the heterogenous group of enzymes collectively termed alkaline phosphatase (EC 3.1.3.1: orthophosphoric monoester, phosphohydrolase, alkaline optimum; ALP) in the serum of patients receiving treatment for epilepsy has been observed by several workers. Richens and Rowe conducted a survey of adult institutionalised epileptic patients, which showed an increase in the serum activity of total ALP.' Siest et al showed that antiepileptic drugs strongly increased the plasma ALP activity in adults (by $24 \%$ in men and $70 \%$ in women) and in children (by $56 \%$ in boys and $53 \%$ in girls). ${ }^{2}$ Skillen and Pierides reported that serum total ALP was increased in seven out of 33 adult epileptic patients receiving anticonvulsant drug polytherapy. ${ }^{3}$ The need, therefore, was to determine the extent of the role of carbamazepine (CBZ, Tegretol, CIBA Geigy). O'Hare et al had shown decreased serum calcium concentration and increased serum total ALP, both of which were significant, in epileptic patients receiving CBZ monotherapy. ${ }^{4}$ Aldenhovel, in 1988 , also reported increased serum ALP activity in $14 \%$ of patients receiving CBZ. ${ }^{5}$ They did not show, however, that ALP isoenzymes were increased.

Our study was carried out to confirm the reported increase in serum total ALP activity in patients receiving CBZ monotherapy, ${ }^{45}$ and also to determine, using a reliable precipita- tion technique, the actual source of the ALP isoenzyme that was increased.

\section{Methods}

Forty one serum samples were selected from those sent to the Drugs Monitoring Laboratory of the National Hospital for Neurology and Neurosurgery, Queen Square, London, for routine estimation of anticonvulsant drug concentrations. Full clinical details of the patients whose sera were to be studied were obtained from their case notes. Only patients receiving $\mathrm{CBZ}$ and with no history or laboratory results suggestive of liver or bone disease were selected. They must have received $\mathrm{CBZ}$ monotherapy for a minimum period of two years at the time the samples were collected.

The 41 samples selected comprised 21 men aged 16-67 years (mean 38 years) and 25 women aged 21-66 years (mean 40 years). Samples used as the reference population were collected from the antecubital vein of 32 age-matched, healthy laboratory workers and staff from other departments in the hospital. Serum was separated from cells within two hours of collection and immediately stored at $-20^{\circ} \mathrm{C}$. The control group comprised 16 men and 16 women, aged 19 to 66 years (mean age 39 years).

\section{MEASUREMENT OF TOTAL ALP}

The serum total ALP was measured at $25^{\circ} \mathrm{C}$ according to the method of the German Society of Clinical Chemistry, ${ }^{6}$ using p-nitrophenol phosphate as substrate and diethanolamine buffer (Merck, Darmstadt, Germany). The method was adapted to the Guildford 3500 discrete analyser.

\section{PRECIPITATION AND CALCULATION OF BONE ALP} ACTIVITY

The precipitation procedure and calculations were performed as described previously. ${ }^{7-9} \mathrm{An}$ aqueous solution of wheat germ lectin (Sigma Chemical Company, Poole, Dorset) was prepared by adding $5 \mathrm{ml}$ distilled water to $25 \mathrm{mg}$ of lyophilised powdered lectin. This gave a concentration of $5 \mathrm{~g} / \mathrm{l}(139 \mu \mathrm{mol} / \mathrm{l})$. To $1 \mathrm{ml}$ of the aqueous lectin solution was added $40 \mu \mathrm{l}$ of Triton X-100 (BDH Chemicals Ltd, Poole, Dorset), so that when mixed with an equal volume of plasma the final incubation concentration of Triton X-100 was $20 \mu \mathrm{l} / \mathrm{ml}$. Fifty microlitres of lectin- Triton X-100 solution was mixed with $50 \mu \mathrm{l}$ of serum and incubated for 30 minutes at $37^{\circ} \mathrm{C}$. This solution was then transferred to a refrigerator and

Correspondence to:

Accepted for publication

10 January 1991 
kept at $+4^{\circ} \mathrm{C}$ for two minutes before centrifugation at $2000 \times g$ for 10 minutes. The supernatant was removed, ALP activity determined, and the measured value was referred to as non-bone ALP. Bone ALP activity was calculated by subtracting the corrected value of non-bone ALP from the total ALP activity, as described by Behr and Barnet. ${ }^{9}$ Because the precipitation characteristics of the batch of wheat-germ lectin used were not checked, it was assumed for calculation purposes that there was a $100 \%$ precipitation of the bone fraction, and that the addition of Triton-X100 would make precipitation of liver ALP fraction negligible. To calculate the total analytical recovery of isoenzyme activities, the precipitates were resuspended in $200 \mu \mathrm{l}$ of isotonic saline and the ALP activity then determined. Summation of the isoenzyme activities of the precipitate and supernatant, followed by an adjustment for sample dilution, produced the value for total recovery of isoenzyme activity.

The significance of differences between the controls and patients receiving CBZ was tested using Student's $t$ test. The significance level was set at $\mathrm{p}<0.05$.

\section{Results \\ ANALYTICAL QUALITY CONTROL \\ Analytical recovery}

To calculate the analytical recovery of total ALP activity from summation of activity in the precipitate and supernatant, 10 sera were examined. The values of total activity on direct measurement ranged between $70 \mathrm{IU} / 1$ and $240 \mathrm{IU} / 1$ (mean $=128$; (SD) $=60 \cdot 7)$. Summation of activities in the supernatant and precipitate measured separately and after adjustment for dilution gave a range of total ALP activity of $66-235 \mathrm{IU} / 1$ (mean 125 , SD 60.0 ), which was equivalent to $98.4 \%$ recovery.

\section{Precision studies}

The between-batch precision $(n=20)$ of the precipitation method was determined by using a pooled serum with total ALP activity of $174 \mathrm{IU} / 1$ and mean bone ALP of $76 \mathrm{IU} / 1$ (range

Summary of total ALP, bone ALP, and non-bone ALP activities in sera of controls and patients receiving $C B Z$ monotherapy

\begin{tabular}{|c|c|c|c|c|}
\hline & \multirow[b]{2}{*}{ Controls } & \multicolumn{3}{|l|}{ Patients } \\
\hline & & All & Women & Men \\
\hline $\begin{array}{l}\text { Number of subjects }(n) \\
\text { Age in years }\end{array}$ & 32 & 41 & 20 & 21 \\
\hline $\begin{array}{l}\text { Range } \\
\text { Mean }(\bar{x}) \\
\text { ISD }\end{array}$ & $\begin{array}{l}19-66 \\
39 \\
14.5\end{array}$ & $\begin{array}{l}16-67 \\
37 \\
14.9\end{array}$ & $\begin{array}{l}21-66 \\
40 \\
15 \cdot 8\end{array}$ & $\begin{array}{l}16-67 \\
35 \\
13.9\end{array}$ \\
\hline $\begin{array}{l}\text { Total ALP (IU/1) } \\
\text { Range } \\
\text { Mean (x) } \\
\text { 1SD }\end{array}$ & $\begin{array}{c}75-170 \\
110 \\
24 \cdot 3\end{array}$ & $\begin{array}{c}59-244 \\
126 \\
51 \cdot 1\end{array}$ & $\begin{array}{c}6-240 \\
128 \\
50 \cdot 5\end{array}$ & $\begin{array}{c}59-244 \\
125 \\
52 \cdot 9\end{array}$ \\
\hline $\begin{array}{l}\text { Bone ALP }(\mathrm{IU} / \mathbf{1}) \\
\text { Range } \\
\text { Mean }(\overline{\mathbf{x}}) \\
\text { 1SD }\end{array}$ & $\begin{array}{l}36-118 \\
60 \\
18 \cdot 2\end{array}$ & $\begin{array}{l}74-208 \\
76 \\
47 \cdot 7\end{array}$ & $\begin{array}{l}14-182 \\
73 \\
49 \cdot 6\end{array}$ & $\begin{array}{l}25-208 \\
79 \\
48 \cdot 8\end{array}$ \\
\hline $\begin{array}{l}\text { Non-Bone ALP (IU/l) } \\
\text { Range } \\
\text { Mean (x) } \\
\text { 1SD }\end{array}$ & $\begin{array}{l}30-120 \\
50 \\
21 \cdot 4\end{array}$ & $\begin{array}{l}12-110 \\
50 \\
26.9\end{array}$ & $\begin{array}{l}17-110 \\
55 \\
27 \cdot 9\end{array}$ & $\begin{array}{l}12-98 \\
46 \\
25\end{array}$ \\
\hline
\end{tabular}

63-96 IU/1). The coefficient of variation (CV) was $4 \cdot 7 \%$ for between-batch precision. The within-batch precision $(\mathrm{n}=8)$ was determined using the same pooled serum and the $\mathrm{CV}$ value was $2 \cdot 3 \%$.

\section{External quality control}

In addition to the above, the control samples from United Kingdom and Wellcome External Quality Assessment Programmes were both included in every batch of measurements. These were the samples used by the laboratory in which this research was carried out during their participation in the external quality control programme. The United Kingdom and Wellcome control samples gave $\mathrm{CV}$ values of $8.07 \%$ and $9.1 \%$, respectively.

\section{OBSERVATIONS AND DEDUCTIONS}

The summation of total ALP, bone ALP, and non-bone ALP activities in the sera of controls and patients receiving $\mathrm{CBZ}$ monotherapy is shown in the table. The SD was generally higher in the patients than in the controls. The reference range for serum total ALP derived from the control group (mean \pm 2 SD) was 61 $159 \mathrm{IU} / 1$. Among the patients receiving CBZ monotherapy, five women and four men (nine out of 41 patients or $22 \%$ ) had serum total ALP values above the upper limit of $159 \mathrm{IU} / 1$. The mean serum total ALP of patients was higher than that of the controls, with values of $126 \mathrm{IU} / 1$ and $110 \mathrm{IU} / 1$, respectively. The difference between the two means was not significant $(p=0.05)$.

The reference range for serum bone ALP derived from the control group (mean $\pm 2 \mathrm{SD}$ ) was 24-96 IU/1.

Among the patients, six women and four men ( 10 out of 41 patients or $24 \%$ ) had serum bone ALP activity above the upper reference limit of $96 \mathrm{IU} / 1$. There was no significant difference when the mean for the controls was compared with that of the patients. Comparison of means for male controls with male patients and female controls with female patients did not show any significant differences $(p=0.05)$. Twenty per cent (two out of 10$)$ of those patients with increased serum bone ALP had normal serum total ALP activity.

Three patients out of a total of 41 (about $7 \%$ ) had increased serum non-bone ALP activity. The values of serum mean non-bone ALP activity were similar in both patients and controls.

\section{Discussion}

Biochemical osteomalacia, as indicated by decreased serum calcium concentration and increased serum ALP activity in patients receiving anticonvulsant drugs, has been observed by several investigators. ${ }^{1341011}$ The cause of this osteomalacia is still not clear, although various mechanisms have been proposed. ${ }^{34} \mathrm{CBZ}$ is a potent anticonvulsant drug which is currently regarded as a first line treatment for generalised (tonic-clonic) and partial epilepsy. ${ }^{12}$ The current view of monotherapy being preferred to polytherapy will 
demand higher dosages of antiepileptic drugs, (such as CBZ), during which subtle metabolic effects may subsequently become more important.

In this investigation we have shown that increased serum total ALP in patients receiving CBZ monotherapy was mainly from bone rather than from liver and other sources. Nine patients out of a total of $41(22 \%)$ had increased serum total ALP above the upper limit of the reference range (159 IU/1). Ten patients out of $41(24 \%)$ had serum bone ALP above the upper limit (96 IU/1). This finding was similar to that of Richens and Rowe ${ }^{1}$ in 1970, and Skillen and Pierides in $1976,{ }^{3}$ both of whom used electrophoresis to show that increased ALP in patients receiving anticonvulsant drugs was due mainly to the bone fraction. Moreover, these previous reports were based on patients receiving polytherapy. O'Hare et al studied 31 patients receiving $\mathrm{CBZ}$ monotherapy and found a significantly higher serum total ALP activity than in matched controls. ${ }^{4}$ Although their result was similar to ours they did not identify the actual isoenzyme of ALP involved. Furthermore, in our results $20 \%$ of patients with increased serum bone ALP had normal serum total ALP. This finding shows that changes in the isoenzyme level of activity may precede a change in the serum total ALP. Earlier workers had suggested that patients on long term high dose single or combined CBZ treatment should have periodic biochemical checks for osteomalacia ${ }^{4}$ there may be a need to proceed to radiological and bone biopsy studies in selected cases.

In our report we have shown that wheatgerm lectin ${ }^{78}$ may be used routinely to measure serum activity of the bone isoenzyme fraction of ALP in such patients. Measurement of bone ALP may provide a more sensitive indicator of osteomalacia than will measurement of total ALP alone, although further investigation is required. The use of wheat-germ lectin is also an improvement on most previous work involving measurement of the isoenzymes of ALP in patients receiving anticonvulsant drugs, which have relied on semiquantitative electrophoretic methods for estimation of the bone fraction. Our thanks go to Mrs Pat Morris and other members of the Department of Chemical Pathology at the National Hospital for Neurology and Neurosurgery, also Dr V Goldberg and staff of
the Drugs Monitoring Laboratory. We thank Professor $\mathrm{H} \mathrm{O}$ the Drugs Monitoring Laboratory. We thank Professor $\mathrm{H} \mathrm{O}$ Adewoye and Dr A O Olukoga for their encouragement. We are
also grateful to Mr Adrian Moore, and Mrs A O Agboola for also grateful to $\mathrm{Mr}$ Adria
typing the manuscript.

This project formed part of the thesis submitted by Dr A B Okesina for Fellowship of the Nigerian Postgraduate Medical College in Chemical Pathology.

1 Richens A, Rowe DJF. Disturbances of calcium metabolism by anticonvulsant drugs. $\mathrm{Br}$ Med $J$ 1970;4:73-6.

2 Siest G, Bati AM, Galtean MM. Interférence des contraceptifs oraux et des anti-épletiques sur les parametres plasmatiques chez l'homme. Étude particulière des enzymes. Therapie 1974;29:907-14

3 Skillen AW, Pierides AM. Serum gamma glutamyl transferase and alkaline phosphatase activities in epileptics receiving anticonvulsant therapy. Clin Chim Acta receiving anticont

4 O'Hare JA, Duggan B, O'Driscoll D, Callaghan N. Biochemical evidence for osteomalacia with carbamazepine chemical evidence for osteomalacia with carb
therapy. Acta Neurol Scand 1980;62:282-6.

5 Aldenhovel HG. The influence of long-term anticonvulsant therapy with diphenylhydantoin and carbamazepine on serum gamma-glutamyltransferase aspartate aminotransferase, alanine aminotransferase and alkaline phosphatase. Eur Arch Psychiatr Neurol Sci 1988;237:312-6.

6 German Society for Clinical Chemistry. Standard method for the determination of alkaline phosphatase activity. $Z$ Klin Chem Klin Biochem 1972;10:191.

7 Rosalki SB, Foo AY. Two new methods for separating and quantifying bone and liver alkaline phosphatase isoenzyme in plasma. Clin Chem 1984;30:1182-6.

8 Rosalki SB, Foo AY. Simplified wheat germ lectin precipitation method for alkaline phosphatase isoenzyme. Clin tion method for $1986 ; 1: 11$.

9 Behr W, Barnet J. Quantification of bone alkaline phosphatase in serum by precipitation with wheat-germ lectin. A simplified method and its clinical plausibility. Clin Chem 1986;32:1960-6.

10 Reynolds EH. Chronic Antiepileptic toxicity. Epilepsia 1975;16:319-52.

11 Dent CE, Richens A, Rowe DJF, Stamp TCB. Osteomalacia with long-term anticonvulsant therapy in epilepsy. $\mathrm{Br}$ Med J 1970;4:69-72.

12 Rapeport WG. Factors influencing the relationship between carbamazepine plasma concentration and its clinical effects in patients with epilepsy. Clin Neuropharmacol in patients 